\title{
EVALUATION OF THE LIME REQUIREMENT OF TROPICAL SOILS IN TERMS OF OTHER SOIL CHARACTERISTICS
}

\author{
M. A. Lugo López, F. Abruña, and J. Roldán ${ }^{1}$
}

\section{INTRODUCTION}

Liming acid soils is a very old soil-management technique that is widely practiced in many progressive agricultural areas, but is still not in very widespread use throughout the Tropics. The dual role of lime in plant nutrition, supplying available calcium and affecting the physiological status of the soil as a medium for plant growth, is well known. Considerable literature have been published concerning many practical aspects of liming. However, there is still a lack of fundamental information regarding the interrelation between the lime requirement and other soil properties. The need for such information is particularly acute when dealing with tropical soils and crops.

This paper reports an attempt to correlate the lime requirement of some tropical soils from Puerto Rico with certain soil characteristics such as $\mathrm{pH}$, cation-exchange capacity, clay content, organic matter, and predominating clay-mineral type. It should be emphasized that for the purpose of this work the lime requirement of a soil is defined as the quantity of limestone required to raise the $\mathrm{pH}$ of an acid soil to 6.5.

\section{Materials and Methods}

The samples used in this study were selected from a large group collected by Jeffries and Bonnet in connection with their study of soil minerals in Puerto Rico soils (2). ${ }^{2}$ The clay minerals were identified by Jeffries by matching X-ray diffraction patterns of the clay fraction with standards of known minerals (1). The clay content was determined by the beaker decantation method. Organic-matter determinations were made using the chromic acid titration method (3). The $\mathrm{pH}$ was obtained by using a Beckman potentiometer. Cation-exchange capacity was determined by the ammonium acetate procedure (5). Lime requirement was determined by adding increments of $\mathrm{CaCO}_{3}$ to several $10 \mathrm{gm}$. soil samples, adjusting the volume of all samples to $150 \mathrm{ml}$. with distilled water, and measuring the $\mathrm{pH}$ values after 3 hours of shaking in a Ross-Kershaw apparatus (4).

${ }^{1}$ Associate Soil Scientist, formerly Assistant Soil Conservationist, now Soil Scientist BPI-SCS Cooperative Research Project, and Research Assistant in Chemistry, respectively, Agricultural Experiment Station, University of Puerto Rico, Río Piedras, P. R.

${ }^{2}$ Numbers in parentheses refer to Literature Cited p. 160 . 


\section{Presentation of Data and Discussion}

The lime requirement of some tropical soils from Puerto Rico included in the investigation varies from 0.2 to 5.8 tons of limestone to the acre, as shown in table 1. A sample of weathered parent material required the equivalent of 9.7 tons to the acre of $\mathrm{CaCO}_{3}$ before reaching $\mathrm{pH}$ 6.5. In 11 soils the predominant clay mineral was found to be kaolin, while minerals of a 2:1 lattice structure, presumably beidellite, were predominant in the

TABLE 1.-The relation of lime requirement to $p H$, cation-exchange capacity, and various other factors for certain tropical soils

\begin{tabular}{|c|c|c|c|c|c|c|c|c|}
\hline Soil type & $\begin{array}{l}\text { Sample } \\
\text { No. }\end{array}$ & Depth & $\begin{array}{l}\text { Predominant } \\
\text { clay mineral }\end{array}$ & $\begin{array}{l}\text { Clay } \\
\text { con- } \\
\text { tent }\end{array}$ & $\begin{array}{c}\text { Cation } \\
\text { exchange } \\
\text { capacity } \\
\text { (dry soil) }\end{array}$ & $\begin{array}{l}\text { Organic } \\
\text { matter }\end{array}$ & $\mathrm{pH}$ & $\begin{array}{c}\text { Lime } \\
\text { re- } \\
\text { quire } \\
\text { ment } \\
\text { per } \\
\text { acre }\end{array}$ \\
\hline & & Inches & & $\begin{array}{l}\text { Per- } \\
\text { cent }\end{array}$ & $\underset{\text { M.e. } / 100}{\text { gm. }}$ & Percent & & Tons \\
\hline Bayamón sandy clay.. & 165 & 18 & & 25.25 & 5.22 & 1.80 & 5.00 & 1.4 \\
\hline Teja loam........... & 70 & 12 & & 10.40 & 7.94 & .37 & 5.15 & .6 \\
\hline Sabana Seca sandy & 194 & 12 & & 2150 & 7.11 & 205 & 570 & \\
\hline Viví sandy loam...... & 73 & $0-15$ & & 14.40 & 7.70 & $\begin{array}{r}2.00 \\
.89\end{array}$ & 4.20 & $\begin{array}{r}.4 \\
2.0\end{array}$ \\
\hline Río Piedras clay...... & 190 & 1 & & 62.17 & 15.11 & 1.03 & 4.10 & 5.0 \\
\hline Las Piedras clay loam & 66 & $0-20$ & & 15.50 & 7.06 & 2.30 & 5.40 & .6 \\
\hline Matanzas clay........ & 119 & 1 & Kaolin & 60.50 & 7.12 & .85 & 5.90 & .4 \\
\hline Cialitos clay.......... & $83 \mathrm{~B}$ & $45+$ & & 19.05 & 13.34 & .52 & 4.45 & 5.8 \\
\hline Catalina stony clay... & 172 & 1 & & 26.17 & 11.16 & .44 & 4.75 & 3.7 \\
\hline Los Guineos clay.... & 186 & $0-24$ & & 3.70 & 8.70 & 7.45 & 5.15 & 1.1 \\
\hline Los Guineos clay..... & 185 & $24-32$ & & 23.15 & 9.18 & 3.83 & 4.85 & 3.0 \\
\hline Cabo Rojo clay....... & 134 & $24-36$ & & 34.25 & 11.29 & 1.49 & 6.10 & .2 \\
\hline Los Guineos clay ..... & 182 & 2 & & 16.95 & 25.91 & .20 & 4.60 & 9.7 \\
\hline Las Piedras clay loam & 64 & $44-48$ & Poidollits & 28.55 & 24.75 & .18 & 5.50 & .2 \\
\hline Múcara silty clay loam & 1 & $0-6$ & Beidellite & 29.87 & 30.97 & 4.84 & 5.55 & .2 \\
\hline Múcara silty clay loam & 2 & $0-3$ & & 33.77 & 30.85 & 4.78 & 5.30 & .4 \\
\hline Múcara silty clay loam & 3 & $3-7$ & & 35.66 & 30.48 & 3.86 & 5.10 & .5 \\
\hline
\end{tabular}

1 Surface.

${ }^{2}$ Decomposed parent material.

remaining 6 samples. The soils selected had an original $\mathrm{pH}$ value ranging from 4.10 to 6.10 , the mean value for all 17 being around $\mathrm{pH} 5.10$. The percentage of clay particles ranged from 3.7 in the upper 2 feet of Los Guineos soil to 62.2 in the surface layer of a Río Piedras lateritic clay. The differences in cation-exchange capacity were very marked, the kaolin dominated soils averaging about 9 m.e. per $100 \mathrm{gm}$. of dry soil while mean values of about 26 m.e. were found in beidellite-dominated soils. There was considerable variability in exchange capacity within the kaolinitic soils, 
but the values for beidellitic soils were fairly constant. The organic-matter content ranged from 0.2 to 7.4 percent with a mean value of 2.2 percent.

Statistical analyses were performed on all the data (table 2 ). The regression of the lime requirement on each individual factor was worked out

TABLE 2.-Analysis of variance for regression analysis of various factors studied

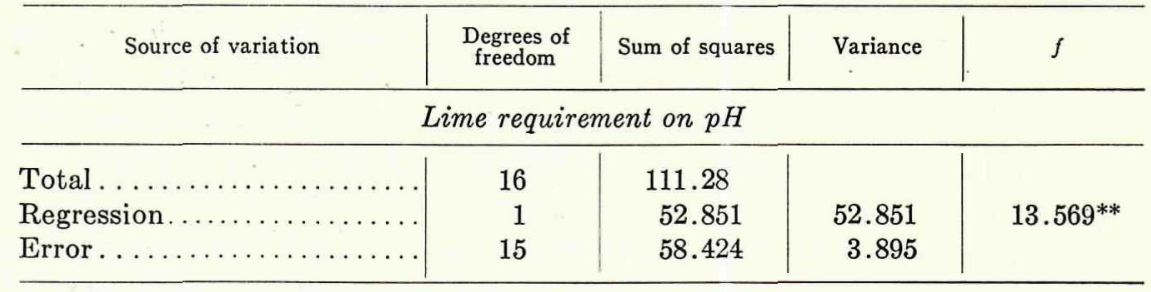

Lime requirement on $p H$ and organic matter

\begin{tabular}{|c|c|c|c|c|}
\hline Total ......... & 16 & 111.28 & & \\
\hline Regression............... & 2 & 59.01 & 29.505 & $7.902^{* * 1}$ \\
\hline Error $\ldots \ldots \ldots \ldots \ldots \ldots \ldots$ & 14 & 52.27 & 3.734 & \\
\hline
\end{tabular}

Lime requirement on $p H$ of kaolinitic soils

\begin{tabular}{|c|c|c|c|c|}
\hline Total $\ldots \ldots \ldots \ldots \ldots \ldots \ldots$ & 10 & 37.176 & & \\
\hline Regression........ & 1 & 23.066 & 23.066 & $14.713^{* *}$ \\
\hline Error . . . . . . . . . . & 9 & 14.110 & 1.568 & \\
\hline
\end{tabular}

Lime requirement on cation-exchange capacity of kaolinitic soils

\begin{tabular}{|c|c|c|c|c|}
\hline Total..... & 10 & 37.176 & & \\
\hline Regression........ & 1 & 29.638 & 29.6380 & $35.387^{* *}$ \\
\hline Error . . . . . . . . & 9 & 7.538 & .8376 & \\
\hline
\end{tabular}

Lime requirement on cation-exchange capacity and $p H$ of kaolinitic soils

\begin{tabular}{|c|c|c|c|c|}
\hline Total. & 10 & 37.176 & & \\
\hline Regression........... & 2 & 32.201 & 16.100 & $25.89^{2 * *}$ \\
\hline Error . ................ & 8 & 4.975 & .6219 & \\
\hline
\end{tabular}

\footnotetext{
${ }^{1} t \mathrm{pH}=-3.417^{* *}$

$t$ o.m. $=-1.476$

${ }^{2} t \mathrm{pH}=-2.03$

$t$ c.e.c. $=3.83^{* *}$
}

taking all soils together without considering whether the predominant clay mineral was kaolin or beidellite. The regression of lime requirement on $\mathrm{pH}$ was found to be: $Y=18.39-3.196 X$, where $Y$ is the lime requirement and $X$ is the $\mathrm{pH}$ value. The regression coefficient is highly significant. A correlation coefficient of -0.70 was obtained. Thus, accurate predic- 
tions of the lime requirement of soils can be made on basis of $\mathrm{pH}$ values exclusively, disregarding any other factors. The organic matter and cationexchange capacity explained part of the variability observed in lime requirements, but no significant regressions were obtained in either case.

A multiple regression was worked out for lime requirement on $\mathrm{pH}$ and organic matter, which were the two factors explaining most of the variability observed in lime-requirement values. There was an increase in the variability explained by this regression but it was not significantly higher than that explained by $\mathrm{pH}$ alone. A correlation coefficient of 0.73 was obtained.

Further statistical analyses were made after arranging the data into two groups according to the predominant clay mineral. For soils dominated by kaolinitic clays the regression of lime requirement on $\mathrm{pH}$ was: $Y=15.26-$ $2.632 X$, where $Y$ is the lime requirement and $X$ is the $\mathrm{pH}$. The regression coefficient is highly significant. A correlation coefficient of -0.80 was obtained which points out to the close degree of association between these two soil characteristics. The regression of lime requirement on cation-exchange capacity of kaolinitic soils was very satisfactory giving the equation: $Y=3.048+0.5774 X$, where $Y$ is the lime requirement and $X$ is the exchange capacity. The regression coefficient was highly significant. A positive correlation coefficient of 0.90 was obtained. About 80 percent of the variability observed in lime requirement values can be explained on basis of the cation-exchange capacity of kaolin-dominated soils.

A regression of the lime requirement on $\mathrm{pH}$ and cation-exchange capacity was worked out. About 87 percent of the variability in lime requirement could be explained in terms of both of these factors taken together. However, the difference in the variability explained by this regression and the one for lime requirement on cation-exchange capacity is not significant.

Further attempts to explain the variability in lime requirement of beidellite-dominated soils in terms of other soil characteristics were not successful. A correlation coefficient of -0.75 was obtained between lime requirement and soil $\mathrm{pH}$, but the regression coefficient was not significant.

When dealing with soils the predominating clay mineral of which is not known, it may be advisable to use the original $\mathrm{pH}$ values as a basis to predict their lime requirement. If the predominating clay mineral is known to be kaolin a better approximation is possible by making use of the regression of lime requirement on cation-exchange capacity, although the regression based on $\mathrm{pH}$ will also give fairly accurate approximations.

More research is contemplated along this line. There is a possibility that more accurrate predictions could be made if a larger number of samples were included in the statistical analyses. This type of equation in addition to giving fundamental information about lime requirements and soil properties affecting it, also provides for farmers, extension agents, and 
teachers of agriculture a rather simple way of estimating the lime needs of soils. This is particularly true of the relation between lime requirement and $\mathrm{pH}$. The latter can easily be determined colorimetrically in the field by any skilled operator.

\section{SumMary}

The quantity of limestone required to bring the $\mathrm{pH}$ of various acid Puerto Rican soils to 6.5 was investigated and found to vary from several hundred to several thousands pounds per acre. To investigate the relation of claymineral type, clay content, cation-exchange capacity, organic-matter content, and $\mathrm{pH}$ to lime requirement, these properties wre determined for several soils. A highly significant regression of lime requirement on $\mathrm{pH}$ was obtained which can be expressed by the equation: $Y=18.39-3.196 X$, where $Y$ is the lime requirement and $X$ is the $\mathrm{pH}$ value. Multiple regressions including other factors did not significantly increase the variability which could be explained on terms of the first regression.

Further analysis were made by arranging the data according to the predominant clay mineral. For kaolinitic soils highly significant correlations were obtained between lime requirement and either $\mathrm{pH}$ or cation exchange capacity. The regressions were: (a) $Y=15.26-2.632 \mathrm{pH}$, and (b) $Y=$ $3.048+0.5774$ (cation-exchange capacity), where $Y$ is the lime requirement.

A regression of lime requirement on both factors did not significantly increase the variability explained by the second equation. No significant regressions were obtained for beidellitic soils.

\section{RESUMEN}

La cantidad de cal necesaria para subir el pH de varios suelos ácidos de Puerto Rico hasta 6.5 fluctúa entre varios cientos y varios miles de libras. Para investigar la relación entre el mineral predominante en la fracción arcillosa del suelo, el contenido de arcilla, la capacidad de intercambio, el contenido de materia orgánica, el valor $\mathrm{pH}$ y la cantidad de cal requerida, fuéque se determinaron estos factores en el laboratorio. Se obtuvo una regresión altamente significativa entre cal requerida y $\mathrm{pH}$ que se puede expresar por la ecuación: $Y=18.39-3.196 X$, donde $Y$ es la cal requerida y $X$ es el valor $\mathrm{pH}$. No hubo un aumento significativo en la variabilidad explicada por la regresión al incluir otros factores.

Los datos se agruparon, luego, de acuerdo con el mineral predominante en la fracción arcillosa. Para suelos donde predomina el caolín se encontraron correlaciones altamente significativas entre cal requerida y $\mathrm{pH}$, y entre cal requerida y capacidad de intercambio. Las regresiones se pueden expresar así: (a) $Y=15.26-2.632 \mathrm{pH}$, (b) $Y=3.048+0.5774$ (capacidad 
de intercambio) donde $Y$ representa la cantidad de cal requerida para subir el pH del suelo a 6.5.

Un intento para establecer una correlación entre la cantidad de cal requerida y ambos factores no aumentó significativamente la variabilidad explicada por la regresión sobre la explicada por la segunda ecuación (b). No se obtuvieron regresiones significativas en el caso de los suelos cuya fracción arcillosa estaba dominada por la beidelita.

\section{Literature Cited}

1. Jeffries, C. D., The use of the X-ray spectrometer in the determination of the essential minerals in soils, Soil Sc. Soc. Amer. Proc. 12 135-140, 1948.

2. Jeffries, C. D., Bonnet, J. A., and Abruña, F., The constituent minerals of some soils of Puerto Rico, unpublished report, Univ. of P. R. Agric. Expt. Sta., 1950.

3. Peech, M., Alexander, L. T., Dean, L. A., and Reed, J. F., Methods of soil analysis for soil fertility investigations; U.S.D.A. Cir. 757, 1947.

4. Riera, A. and Bonnet, J. A., La recomendación del laboratorio sobre la cantidad de cal que se le añadió a un suelo ácido concuerda con el pH esperado, El Crisol 1(5) 3-5, 1947.

5. Schollenberger, C. J., and Simon, R. H., Determination of exchange capacity and exchangeable bases in soil-ammonium acetate method, Soil Sc. 59 13-24, 1945. 